Bu makaleye atıfta bulunmak için/To cite this article:

AKILMAK TOPÇU, S. URAL, S. (2021). 27 Mayıs Darbesi Sürecinde Basında İstanbul-Ankara Öğrenci Olayları. Atatürk Üniversitesi Sosyal Bilimler Enstitüsü Dergisi, 25 (4), 1674-1691.

\title{
27 Mayıs Darbesi Sürecinde Basında İstanbul-Ankara Öğrenci Olayları*
}

\author{
Sema AKILMAK TOPCCU ${ }^{(* *)}$ \\ Selçuk $U R A L^{(* * *)}$
}

Öz: 18 Nisan 1960'da Tahkikat Komisyonu ve 27 Nisan'da bu komisyona geniş yetkiler taniyan Salahiyetler Kanunu'nun mecliste kabul edilmesinden bir gün sonra İstanbul ve Ankara'da üniversite öğrencilerinin başını çektiği protesto gösterileri başladı. Demokrat Parti hükümeti tarafindan bu iki șehirde siklyönetim ilan edilerek sert tedbirler uygulandi. Bu tedbirler kapsaminda basina da müdahale edildi ve protestolarla ilgili her türlü haber yapılması yasaklandl. Yasaklara riayet etmeyen gazetelere bir müddet kapatma cezası verilirken, ilgili nüshalar toplatıldl. Bu nedenle 27 Mayls darbesine kadar dönemin gazetelerinde İstanbul ve Ankara'daki olaylarla ilgili haberlere rastlamak adeta imkânsızdır. Darbeden sonra cuntactlar müdahalenin meşruiyetini kamuoyuna anlatmak için DP iktidarını akıllara durgunluk veren suçlamalarla itham etmeye başladılar. İstanbul-Ankara olaylarında çok sayıda öğrencinin hükümet tarafindan canice öldürüldüğü, cesetlerinin yem makinalarında kıyllıp toz haline getirildiği iddiaları basında genis yer buldu. Hatta dönemin gazeteleri hayatını kaybeden ögrenciler adına anıt yapılması için kampanyalar başlattılar. Harp Okulu ögrencilerinin ortadan kaldırılması için planlar yapıldı̆̆ı, gömülmüş silah ve askeri malzemeler bulunduğu gibi iddialara da dönemin gazetelerinde rastlanmaktadır.

Anahtar Kelimeler: 27 Mayls, DP, basın, İstanbul-Ankara Olaylarl.

\section{Istanbul-Ankara Student Upheavals in The Press During the May 27 Coup}

Abstract: One day after the establishment of the Committee of Inquest on April 18, 1960 and the adoption of the Law of Police Powers, which gave this committee broad powers, on April 27, protests led by university students began in Istanbul and Ankara. Martial law was declared in these two cities by the Democratic Party government and harsh measures were implemented. Within the scope of these measures, the press was also intervened and any news about the protests was prohibited. While the newspapers that did not comply with the prohibitions were sentenced to

${ }^{*} \mathrm{Bu}$ çalışma, Kafkas Üniversitesi, Sosyal Bilimler Enstitüsü, Tarih Anabilim Dalı, Türkiye Cumhuriyeti Tarihi Yüksek Lisans Programında, Sema Akılmak Topçu tarafindan, Prof. Dr. Selçuk Ural danışmanlığında tamamlanan "27 Darbesi Sürecinde İstanbul-Ankara Öğrenci Olayları" başlıklı yüksek lisans tezinden üretilmiştir.

${ }^{* *}$ Bilim Uzman1, (e-posta: semakilmaktopcu @ hotmail.com)(D ORCID ID. https://orcid.org/00000002-8066-8443

${ }^{* * *)}$ Prof. Dr., Kafkas Üniversitesi Fen-Edebiyat Fakültesi Tarih Bölümü (e-posta: sural25@hotmail.com) (D) ORCID ID. https://orcid.org/0000-0001-9206-6661

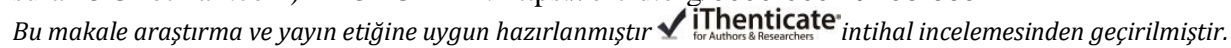


close down for a while, the relevant copies were confiscated. For this reason, it is almost impossible to come across news about the upheavals in Istanbul and Ankara in the newspapers of the period until the May 27 coup. After the coup, the junta began to accuse the DP government with mind-blowing accusations to explain the legitimacy of the coup to the public. The allegations that a large number of students were murdered feloniously by the government in the IstanbulAnkara upheavals and their bodies were chopped in feed machines and pulverized were widely covered in the press. The newspapers of the period even launched campaigns to build monuments for students who lost their lives. There are also allegations that plans were made to exterminate the cadets of the Military Academy and that there were buried weapons and military equipment.

Keywords: May 27, DP, press, Istanbul-Ankara upheavals.

Makale Gelis Tarihi: 08.11.2021

Makale Kabul Tarihi: 16.12.2021

DOI:10.53487/ataunisosbil.1020456

\section{Giriş}

1957 seçimleri sonrasında DP ve CHP arasındaki gerginlik artmaya başladı. CHP lideri İnönü, DP'ye karşı sert bir muhalefet yürüterek diğer partilerle güç birliği yaptı. DP, Vatan Cephesi'ni kurarak bu ittifaklara cevap verdi. Ekonomik sıkıntılar ve huzursuzluklar arttıkça iktidarın tavrı daha da sertleşti. CHP'nin hırçın muhalefeti DP'yi farklı uygulamalara itti. Siyasi krizler ve toplumsal kutuplaşmalara paralel olarak, 1956 yılından sonra üniversite-iktidar çatışması da giderek büyüdü. 1958'in sonlarından itibaren CHP ve DP'liler arasındaki gerilim Uşak, Topkapı, Çanakkale ve Kayseri olaylarıyla tavan yaptı (Yücel, 2001: 137-140). Gelişen olaylar karşısında muhalefeti kısıtlayıcı bir dizi yeni önlemler alma gereğini duyan DP'liler, Tahkikat Komisyonu kurulması önerisini gündeme getirdiler (Bulut, 2009:136). ${ }^{1}$

DP Bursa Milletvekili Mazlum Kayalar ve Denizli Milletvekili Baha Akşit tarafından 14 Nisan 1960'da verilen takrirde; “CHP'nin yıkıcı, gayrimeşru ve kanun dışı faaliyetlerinin memleket sathinda cereyan tarzl ve bunlarin mahiyetinin nelerden ibaret olduğunu tahkik, tespit ve memleketin her tarafinda yaygin bir halde görülen kanun dişı siyasi faaliyetlerin muhtelif sebeplerine intikal etmek, matbuat meselesi ile adli ve idari mevzuatın ne suretle tatbik edilmekte olduğunu tetkik eylemek üzere Meclis tahkikatı açılması" isteniliyordu. Takrir 18 Nisan 1960 tarihinde TBMM Genel Kurulu'na geldi ve DP'li milletvekillerinin oylarıyla kanunlaştı (TBMM Zabıt Ceridesi, 18 Nisan 1960: 189-191). 27 Nisan'da ise büyük tartışmaların ardından komisyona geniş yetkiler tanıyan

1 Bayar'a göre CHP, iktidarın kendisinden uzaklaşmakta olduğunun farkına vardığından hırçınlaşıyor, iktidarı bükmeye çalışıyordu. İktidar ise muhalefeti kendi düzeninde tutmaya gayret ediyordu. Aksiyon ve reaksiyon birbirini kovalıyor ve neticede Tahkikat Komisyonu kuruluyordu. Böylece iktidar ve muhalefet dar bir boğaza giriyordu. (Bozdağ, 2010: 238). Şevket Süreyya Aydemir'e göre: “DP idarecilerinin, artı idare edilemez hale geldiğini saydıklart memleketi kendilerinde düzene sokabilmek için ilk başvurdukları tedbir, olağanüstü yetkili bir Meclis Tahkikat Komisyonu'nun kurulmasını düşünmek oldu. Tahkikat Komisyonu aslında, meclis ve devlet üstünde devlet gibi bir şeydi. Hedef, CHP'nin ve basının yaratığı ve DP'nin hoş görmediği gidişatın önlenmesiydi." (Aydemir, 1988: 395). 
“Salahiyetler Kanunu” kabul edildi (TBMM Zabit Ceridesi, 27 Nisan 1960: 301-302). Salahiyetler Kanunu'nun TBMM'de kabul edilmesinden bir gün sonra İstanbul'da, iki gün sonra da Ankara'da binlerce öğrencinin katılımıyla hükümeti protesto gösterileri başladı (Yücel, 2001: 142). ${ }^{2}$

Olaylar başladıktan bir süre sonra İstanbul Valisi Ethem Yetkiner hükümete "derhal sıkıyönetim ilan edilmesi” " teklifinde bulundu. Hükümet de teklife uyarak saat 15.00'ten itibaren İstanbul ve Ankara'da sıkıyönetim ilan etti. İstanbul Sıkıyönetim Komutanlığına Org. Fahri Özdilek, ${ }^{3}$ Ankara Sıkıyönetim Komutanlığı'na da Korg. Namık Argüç ${ }^{4}$ getirildi. Sıkıyönetim ilanı, olayların 29 Nisan 1960 Cuma günü Ankara'ya sıçramasına engel olamadı. Ankara olayları aynı gün Hukuk Fakültesi'nde başladı. Kısa sürede Siyasal Bilgiler Fakültesi’ne sıçrayan gösterilerde "diktatör kahrolsun" ve "Menderes istifa” sloganları atıldı (Yücel, 2001: 142).

28 Nisan'da İstanbul'da başlayan olaylarla ilgili İçişleri Bakanlığı'nın yaptığı açıklamaya göre yakalanan göstericilerin bazılarının ceplerinde CHP pankartları bulunmuştu. $\mathrm{Bu}$ hadiseler esnasında 15 polis memuru yaralandı ve hastaneye kaldırıldı. Yaralılardan birinin durumu ağırdı. Buna karşın göstericilerden Orman Fakültesi

\footnotetext{
${ }^{2}$ Ali Fuad Başgil anılarında İstanbul Üniversitesi'ndeki olaylarla ilgili olarak; 26 Nisan'da üniversiteye gazetecilerin geldiğini ve kendisine Tahkikat Komisyonu'yla ilgili sorular sorduklarını, kendisinin de gazetecilere meclisin böyle bir komisyon kurmaya yetkisinin olduğunu, komisyonun ne gibi yetkileri olacağına dair ortada bir bilgi olmadığını (Salahiyetler Kanunu 27 Nisan'da mecliste kabul edildi, 28 Nisan'da gazetelerde yayınland1) ve bu nedenle konuyla ilgili açıklama yapamayacağını söylediğini belirtir. Fakat aynı gün kendileriyle mülakat yapılan diğer hukuk hocaların komisyon aleyhinde açıklamalar yaptıklarını ve bu hocaların beyanatlarının gazetelerde yayınlandığını, kendisinin açıklamalarının ise yayınlamadığını anlatır (Başgil, 2007: 124). Ahmet Emin Yalman'a göre; Prof. Dr. Nail Kubalı Tahkikat Komisyonu'nun kurulmasının istibdat yolunu tutmak anlamına geldiğini dersi esnasında öğrencilerine söyledi. Bunun üzerine 28 Nisan olayları başladı. Polis ise üniversiteye geldiğinde öğrencileri çileden çıkarmak için ne gerekiyorsa yaptı. Rektör Sıddık Sami Onar'ın yanlış yol tutulduğu şeklindeki önerilerini dikkate alan olmadı. Olaylar başladıktan kısa bir süre sonra bazı öğretim üyeleri, avukatlar ve doktorlar hükümeti protesto yürüyüşleri yaptılar. Cübbelerini Taksim anıtının önüne astılar. Menderes bu hadisenin ardından "kara cübbeliler" diye bir ifade kullandı. Daha sonra etrafındakilerin uyarısıyla bu sözün gazetelerde yayımlanmaması için uğraşıldı fakat geç kalındı (Yalman: 351). 3 "1916 tarihinde Piyade Teğmeni olarak orduya katıldl. I. Dünya Savaşı sırasında Irak ve Kafkas Cephelerinde görev yapan Özdilek, Kurtuluş Savaşı'nda da katıldı. 1935 yllında Harp Akademisini bitirdikten sonra birlik kumandanlıklarında ve Milli Savunma Bakanlı̆̆ Müsteşarlı̆̆ında bulundu. Sikıyönetim ilan edildiği dönemde 1. Ordu Komutanlı̆̆ görevinde bulunuyordu" (Milliyet, 29 Nisan 1960).

4 "1915 yılında orduya katıldı. 1. Dünya Savaşı yıllarında Sina Cephesinde görev yapan Argüç, Kurtuluş Savaşında aktif görev aldl. Kore’ye gönderilen Türk askeri birliği içerisinde 2. Türk Tugayı Komutanı olarak görev yaptı. 6-7 Eylül olaylarından sonra İstanbul Sıklyönetim Bölge Komutanlı̆̆ yapan Argüç, 3. ve 5. Kolordu Komutanlı̆̆ı görevlerinde de bulundu” (Milliyet, 29 Nisan 1960).
} 
öğrencisi, Malatya doğumlu Turan Emeksiz öldü, ikisi ağır olmak üzere 16 kişi ise yaralandı (BCA. 010.09.7.23.7.40). ${ }^{5}$

İçişleri Bakanlığı'nın Ankara'da yaşanan hadiselerle ilgili olarak yaptığı açıklamada; 29 Nisan 1960 günü sabah saat 09:30 sıralarında Ankara Hukuk ve Siyasal Bilgiler Fakültesi öğrencilerinden 300-400 kişinin fakülte bahçesinde toplanmasıyla olayların başladığı belirtiliyordu. Ardından olay yerine gelen Sıkıyönetim Komutanı ve güvenlik görevlilerinin dağılın ihtarına öğrencilerin mukavemet göstermeleri üzerine zor kullanılmak mecburiyetinde kalındığı, öğrencilerin ise taş ve cam parçalarıyla karşılık verdikleri, yaşanan arbededen sonra göstericilerden 58 kişinin gözaltına alındığ açıklandı. Bu olaylar esnasında 7 polis, 3 itfaiye mensubu ve 1 asker ile göstericilerden 11 kişi yaralandı. İçişleri Bakanlığı'nın açıklamalarına göre bu olaylar esnasında göstericilerin arasında onları teşvik ve protesto hareketlerini desteklemek amacıyla CHP'li milletvekillerinden Ahmet Üstün, Ferda Güley, Ahmet Frrat, Melih Küçüktepepınar, Muslihittin Yılmaz ve Turan Feyzioğlu'nun da bulunduğu ve protestolar devam ettiği sürece oradan ayrılmadıklarının tespit edildiği belirtiliyordu (BCA. 010.09.7.23.7.41). Söz konusu dönemde iktidar muhalefeti yıldırmak için meclisteki gücünü kullanırken, muhalefet de meclis dışındaki güçleri iktidara karşı örgütlüyordu (Taşyürek, 2009: 109).

Demokrat Partililere göre bu hadiseler karanlık eller tarafından organize edilmiş ve öğrenciler sokaklara dökülmüştü. Başbakan Adnan Menderes, olayların patlak vermesinin ardından 29 Nisan'dan 2 Mayıs'a kadar her gün radyodan vatandaşlara seslendi ve olup bitenleri birinci ağızdan anlattı. Ardından Batı Anadolu gezisine çıkan Menderes, gittiği yerlerde düzenlediği mitinglerde İstanbul ve Ankara'da yaşanan hadiselere değindi. Menderes konuşmalarında özellikle, protestoların bir üst akıl tarafından organize edildiği ve tamamen yalan haberlerle insanların kandırıldığına vurgu yapıyordu. Ayrıca CHP'li bir grup yöneticiyi hadiselerden sorumlu tutarak günden güne

\footnotetext{
${ }^{5}$ Olaylarla ilgili bir başka çarpıcı husus ise, bir yerde bitip, az zaman sonra olmadık yerde yeniden patlak vermesiydi. Bu ise olayların tek elden kontrol edildiği ve yönlendirildiği kuşkularını artırıyordu. 27 Mayıs darbesinde harekâtın İstanbul ayağını planlayan Kurmay Binbaşı Şefik Soyuyüce'nin, öğrenci eylemlerinin bizzat kendileri tarafından organize edildiğini açıklaması, bu konudaki tartışmaları daha da önemli hale getirmektedir. Soyuyüce, özellikle 28 Nisan 1960'tan sonraki öğrenci eylemlerinin kendi kontrollerinde yapıldığını söyleyerek, "Öğrencileri 4-5 kamyona bindirip bir yerde biraklyor ve 'şurada gösteri yapsınlar' diyorduk." demektedir. Soyuyüce; "ihtilal öncesinde İstanbul Üniversitesi Mediko-Sosyal'de kendi arkadaşı olan iki doktor vasıtasıyla öğrencilerle temas kurduklarını, öğrencilerle kendileri arasındaki diyaloğu onların sağladığını ve karargâhı da oraya kurduklarını" ifade etmiştir. Öğrencilere yiyecekleri bile kendilerinin getirdiklerini anlatan Soyuyüce, "Tümenden üç kamyon dolusu helva, peynir, ekmek getirdim, üniversitenin arka kapısından içeriye soktum, çocuklara dağıttık. Ondan sonra, bütün 28 Nisan'dan sonraki hareketler bizim kontrolümüzde yapıldı." şeklinde açıklamalarıyla, olaylarda askerin rolünü ortaya koymaktadır. Bu konudaki bir başka iddia ise bazı subayların sivil kıyafetler giyerek gösterilere katıldığı şeklinde idi. Nitekim bu olaylarda bizzat rol almış ve kitleleri tahrik ederek öğrencileri polise saldırtan elebaşlarından hemen hemen hiçbirisi Yassıada' da yargılanmazken, bu olaylara müdahale eden polislerin hepsi yargılanıp çeşitli cezalara çarptırılması bu konudaki iddiaları güçlendirmektedir. (Dikici 2014: 21-22).
} 
sertleşen bir üslupla eleştirilerini sürdürüyordu (Topçu, 2019: 2460-2461). Tahkikat Komisyonu'na yetki veren kanunun kabul edilmesinden bir gün sonra İstanbul'da, iki gün sonra da Ankara'da binlerce öğrencinin katılımıyla başlayan hükümeti protesto gösterileri 27 Mayıs darbesine kadar devam edecekti. ${ }^{6}$ Darbeden sonra Türk siyasi tarihinin en tartışmalı mahkemelerinden olan Yassıada Mahkemeleri'nde Demokrat Partililer farklı farklı suçlardan yargılandı. İstanbul ve Ankara'da gösterilere sebep olan Tahkikat Komisyonunun kurulması ve ardından sıkıyönetim ilan edilmesi ise anayasayı ihlal davasının en önemli dayanağı haline getirilecekti (Topçu, 2018: 731).

\section{Darbe Öncesi Basında Öğrenci Olayları}

DP döneminin basın merkezi İstanbul'dur. Bu dönemde; Cumhuriyet, Milliyet, Hürriyet, Akşam, Tasvir, Yeni Sabah, Yeni İstanbul, Gece Postası ve kısmen Vatan gazeteleri tarafsız yayın yapma çizgisindeydiler. Ulus CHP'nin, Zafer DP'nin ve Kudret gazetesi de Millet Partisi'nin yayın organı gibi davranmaktaydı. Dünya, Vakit ve Tercüman CHP taraftarıyken; Son Posta ve Her Gün DP taraftarıydı (Kaya, 2010: 96).

Sıkıyönetim ilan edilmeden önce basında Tahkikat Komisyonu ile ilgili bazı köşe yazılarının yazıldığı görülmekle beraber, sıkıyönetim ilanından sonra basında bu tür yazılara yer verilmediği görülmektedir. 27 Nisan'da Cumhuriyet gazetesinde Tahkikat Komisyonu ile ilgili Nadir Nadi tarafından kaleme alınan yazıda; bu tedbirlerin iktidarı huzura kavuşturmayacağı, tam tersine iktidarla beraber halkın da huzurunun bozulacağı, her tedbirden sonra yenisine başvurmak gerekeceği ifade ediliyordu. Devamında, içeriye ve dışarıya demokrat görünüp, ülkenin fiili olarak tek parti rejimiyle yönetilemeyeceğini, kanunun kabul edilmesinden sonra Türkiye'de hürriyet rejiminin göstermelik kalacağını söyledikten sonra: "Komisyon dilediği kimseyi dilediği gibi sorguya çekecek, evlerde, bürolarda araştırmalar yapacak, her türlü evrak ve benzeri eşyayı zapt edebilecek, vatandaşlara ceza verebilecek, gazeteleri kapatabilecek, hatta matbaaları kapatabilecektir. Komisyon bu tasarruflara karşı vatandaşa hiçbir itiraz hakkı tanımayacaktır. Itiraf edelim ki bu şartlar altında hukuk rejiminin himayesi altında yaşadığımızı iddia etmek güç olacaktır” diyordu. Yazısının sonunda ise, bu anlayışın akıbetinin hüsran olacağını ve uzun zaman payidar olamayacağını ifade ediyordu (Nadir Nadi, Nasıl Bir rejime gidiyoruz? Cumhuriyet, 27 Nisan 1960).

${ }^{6}$ CIA'nın 20 Nisan 1960 tarihli raporunda DP ile CHP arasındaki siyasi krize dikkat çekilmiştir. CIA, Tahkikat Komisyonu tarafindan üç aylığına tüm siyasi faaliyetlerin yasaklandığının altını çizmiş, 19 Nisan'da Ankara'daki gösterilere polisin sert müdahale ettiğini belirtmiştir. Bu süreçte DP'nin CHP faaliyetleri üzerinde sınırlayıcı önlemler alacağını ve bu unsurların partiyi kapatmaya kadar gideceğini iddia etmiştir. Ülkede her geçen gün tansiyonun arttığına dikkat çeken CIA, DP'ye muhalif olanların yer altı faaliyetlerinin artacağını vurgulamıştır. İsmet İnönü'nün Kayseri Yeşilhisar ziyareti sırasında yaşanan gerginliğin ülkedeki siyasi tansiyonu iyice artırdığına vurgu yapan CIA, bu sırada istifa eden dört subayın tutuklandığını ifade etmiştir. CIA, Milli Mücadele komutanlarından ve Mustafa Kemal Atatürk'ün yakın arkadaşlarından olan İsmet İnönü'ye karşı hükümetin takındığı tavrın ordu içerisinde rahatsızlığa neden olduğunu ifade etmiştir. Bu durumun ordunun üst düzeyinde Menderes Hükümetine desteğinin tehlikeye düştüğüne dikkat çekmiştir. Bu nedenle ülkedeki siyasi çekişmenin hem demokrasiyi hem de ülkenin güvenliğini tehdit ettiğini belirtmiştir. (Akça ve Kıyanç, 2018: 533). 
28 Nisan'da Ulus gazetesinde Yakup Kadri Karaosmanoğlu tarafindan kaleme alınan yazıda: "bizi alkışlamak isteyenlerin kimini coplarla dağıttınız, kimini karakol karakol sürüklediniz, kimini ă̆ır ceza mahkemelerinde yargllatıp hapse attırdinız... Sizden olmayanları asilik ve bozgunculuk suçlarıyla itham etmektesiniz. Bütün bunları Toplantı ve Gösteri Yasağı Kanununa dayanarak yapıyorsunuz. Hâlbuki kendiniz bu yasaklara hiç riayet etmiyorsunuz... İstediğiniz zaman istediğiniz yerde istediğiniz gibi mitingler yapıyorsunuz. Bizim toplantılarımız için 'kapalı yerlerde toplanacaksınız, sesiniz bile dışarıya çıkmayacak' dediniz" diyerek iktidarın koyduğu yasakları eleştirildiği görülmektedir (Yakup Kadri Karaosmanloğu, Niçin? Niçin? Ulus, 28 Nisan 1960).

Tahkikat Komisyonu'na geniş yetkiler veren Salahiyetler Kanunu'nun meclis komisyonunda kabul edilmesini Milliyet gazetesi, "fevkalade yetkiyi encümen kabul etti" başlı̆̆ıla okurlarına duyurdu. Haberin içeriğinde 26 Nisan gecesi geçici komisyonda görüşülen kanun teklifinin 27 Nisan'da meclisin gündemine geleceği belirtiliyordu. Komisyonda sadece ikinci maddede değişiklik yapılarak gazete ve matbaa kapatma yetkisinin şarta bağlandığ gazete ve matbaalar kapatılabilir" şekliyle kabul edildiği aktarılıyordu. Gazete DP Balıkesir Mebusu Sitkı Yırcalı'nın kanun teklifini şiddetle reddettiği ve "teklif anayasamıza ve hukuk sistemimize külliyen aykırıdır" dediğini naklediyordu. Yedi saat süren görüşmelerin ardından DP'li mebusların oylarıyla kanun teklifi kabul edilirken, CHP'li mebuslar toplantıyı terk etti (Milliyet, 27 Nisan 1960). Milliyet gazetesi aynı gün "bu teklif kanunlaşmamall" başlığıyla yayınladığı yazıda Cumhuriyet devrinde hiçbir müesseseye tanınmamış fevkalade yetkilerin bir komisyona verilmesiyle meclisin üstüne çıkartıldığını iddia ediyordu. ${ }^{7}$

Salahiyetler Kanunu'nun meclis komisyonunda onaylanmasını Cumhuriyet gazetesi "komisyon sert tenkitlerden sonra dün teklifi kabul etti" başlığıyla verdi. Haberin devamında DP Balıkesir Mebusu Sitkı Yırcalı'nın: "böyle bir yetkiyi bir gayri mesul heyete vermek Sikıyönetim Kanununda kabul edilmiş yetkilerin bile ilerisindedir. Yalnız anayasaya değil adli sisteme de uygun düşmez" şeklinde yaptı̆g konuşmasına yer veriliyordu (Cumhuriyet, 27 Nisan 1960). Hürriyet gazetesi ise tasariya muhalefet partisinin yanı sıra Sıtkı Yırcalı'nın da itiraz ettiğini aktarıyordu (Hürriyet, 27 Nisan 1960).

28 Nisan'da Milliyet gazetesi “olağanüstü yetkiler kabul edildi" başlı̆̆ıyla kanun teklifinin yasalaştığı ve meclis müzakerelerinin yayınlanmasının Tahkikat Komisyonu tarafindan yasaklandığı bilgisini birinci sayfadan okuyucularına duyurdu (Milliyet, 28 Nisan 1960). Cumhuriyet gazetesi, Tahkikat Encümeni'ne ait yeni kanun çıktı, dünkü meclis görüşmelerinin neşri yasak edildi" başlı̆̆ıla kanuna dikkat çekiyordu (Cumhuriyet, 28 Nisan 1960). Hürriyet gazetesi ise "encümenin salahiyet kanunu kabul edildi, İnönü 12 celse meclisten çıkartıldl" başlı̆ıyla haberi aktarıyordu. Haberin

\footnotetext{
7 Anayasa nizamının ve onun teminatı altında bulunan hak ve hürriyetlerimiz teklifin kanunlaşmasıyla ortadan kaldırılmış olacaktır. Siyasi partilerin ve basının bu şartlar altında vazifelerine ne derece devam edebileceği meçhuldür. Dünya umumi efkarının antidemokratik hareketlere karşı çok hassas olduğu şu sırada Büyük Meclisin böyle bir kanunu tasvip etmeyeceğine inanmak arzu ve ihtiyacındayız." (Milliyet, 27 Nisan 1960).
} 
devamında 12 CHP mebusunun 3 ila 6 celse meclisten çıkartılma cezaları aldıkları beyan ediliyordu (Hürriyet, 27 Nisan 1960).

29 Nisan'da ise Sıkıyönetim kararı çeşitli yönleriyle duyuruluyordu. Milliyet gazetesi birinci sayfadan "dün saat 15'te Ístanbul ve Ankara'da ilan edilen Sikıyönetim, vuku bulan hadiselerin neşrini men etti" diyerek haber yayınına kısıtlama getirildiğine dikkat çekiyordu. Gazete haberin devamında, Sıkıyönetimin ilanının ardından Ankara Radyosu'nda yayınlanan tebliğlere yer veriyordu. ${ }^{8}$

Cumhuriyet gazetesi "Ístanbul ve Ankara'daki hadiseler üzerine iki şehirde sıkıyönetim ilan olundu" (Cumhuriyet, 29 Nisan 1960). Ulus gazetesi, "Ístanbul ve Ankara'da sıkıyönetim, İstanbul'daki hadiselerin neşri yasak" manşetiyle (Ulus, 29 Nisan 1960), Hürriyet gazetesi ise "Istanbul-Ankara'da slklyönetim ilan edildi, Orgeneral Fahri Özdilek İstanbul, Korgeneral Namık Argüç Ankara sıkıyönetim komutanı oldular" başlığıyla gelişmeyi duyuruyordu (Hürriyet, 29 Nisan 1960).

Sıkıyönetim ilan edilmesinden sonra hızla basına kısıtlamalar getirildi. Dolayısıyla İstanbul ve Ankara'da yaşanan hadiselerle ilgili teferruatlı bilgi verilemediği görülmektedir. Tahkikat Komisyonu ya da Sıkıyönetim Komutanlığı olaylarla ilgili resim, karikatür ya da farklı türlerde haberlerin yayınlamasını yasakladığından ve buna uymayan haber ya da görsellerin yer aldığı sayılar devamlı suretle toplatıldı. Bu nedenle basında Sıkıyönetim Komutanlıklarının ve Tahkikat Komisyonu'nun tebliğleri dışında çok fazla bilgi ve detay yer almamaktadır.

29 Nisan'da Tahkikat Komisyonu'nun yayınladığı tebliğle her ne suretle olursa olsun toplant 1 tertip etmek ve tertiplenen toplantılara katılmak yasakland.. Ayrıca, İstanbul ve Ankara'da Sıkıyönetim kararının tatbikine dair TBMM'de cereyan eden müzakereler, Resmi Gazete ile Tahkikat Encümeni’nin, hükümetin ve Sıkıyönetim Komutanlıklarının yapacakları resmi beyan ve tebliğler haricinde her türlü haber, makale, fikra, resim ve yazıların neşri yasaklandı (Milliyet, 30 Nisan 1960).

Çıkan olaylardan dolayı 29 Nisan tarihli gazeteler, İstanbul ve Ankara'daki üniversite ve yüksekokullar bir ay süre ile kapatıldığını yazıyordu. Tahkikat Komisyonu kararıyla 29 Nisan tarihli meclis müzakerelerinin yayınlanmasının yasaklandığ duyuruldu. Aynı gün Adnan Menderes radyodan açıklamalar yapmaya başladı. Menderes'in konuşmaları radyolardan gün içerisinde sık sık yayınlanırken, konuşmaların tam metni basında da yer ald1 (Milliyet, 30 Nisan 1960: 5)

Milliyet ve Cumhuriyet gazeteleri 30 Nisan'da İstanbul ve Ankara'da üniversite ve yüksekokulların bir ay süre ile kapatıldığını, Tahkikat Komisyonu'nun bütün toplantıları yasak ettiğini duyurdu. Aynı günkü gazetelerde Adnan Menderes'in radyo konuşmasının ve Sıkıyönetim Komutanlığı'nın yayınladığı tebliğin tam metni verildi. Ayrıca İçişleri Bakanlığı'nın açıklamasına paralel olarak üniversite hadiselerinde bir öğrencinin öldüğü,

${ }^{8}$ Radyoda: 28 Nisan günü saat 15 'ten itibaren İstanbul ve Ankara vilayetlerinde sıkıyönetim ilan edildiği; İstanbul Sıkıyönetim Kumandanlığı'na Orgeneral Fahri Özdilek ve Ankara Sıkıyönetim Kumandanlığı'na Korgeneral Namık Argüç tayin edildiği bilgisini paylaştığını ifade ediyordu. (Milliyet, 29 Nisan 1960). 
31 kişinin de yaralandığı belirtildi (Milliyet, 30 Nisan 1960-Cumhuriyet, 30 Nisan 1960). Hürriyet gazetesi ise okulların tatil edilmesinden başka, Sıkıyönetim tarafından taşralı öğrencilerin derhal memleketlerine dönmelerine karar verildiğini duyurdu (Hürriyet, 30 Nisan 1960). ${ }^{9}$

İstanbul Sıkıyönetim Komutanlığı'nın gazetelerde çıkan haberlerin dışında sayfa yapısına da müdahale ettiği 8 numaralı tebliğden anlaşılıyordu. Tebliğde; gazetelerin başlıklarında 72 puntodan büyük harf kullanılması, sürmanşet, dişi klişe, espaslı manșet ve 4 sütundan büyük resim kullanmak yasaklandı (BCA. 010.09.7.23.7.3.14).

1 Mayıs'ta 24 saat süreyle sokağa çıkma yasağı ilan edilirken, gazetecilerin kendilerine en yakın karakoldan alacakları vesika ile gazete satışı yapabilecekleri duyuruldu (BCA. 010.09.7.23.7.3.15). 9 Mayısta İstanbul'da yasakların biraz daha esnetildiğini görüldü. İbadethaneler, seansları 20 'de bitmek suretiyle opera, tiyatro ve sinemalar, içkisiz olmak üzere bütün büfe ve kantinler, gazinolar, 25 kişiyi geçmeyen idare heyeti toplantıları, nikah törenleri, düğ̈̈n ve konserler diğer yasaklara riayet etmek koşuluyla serbest bırakıldı. Cenaze törenleri için 6 taksi veya bir otobüse müsaade edildiği açıklandı (BCA.010.09.7.23.7.3.19). Hürriyet gazetesi bu gelişmeyi okurlarına "ibadethaneler ile sinema açıllyor" başlığıyla duyurdu. Haberde sinema ve tiyatroların seanslarının 20 'de biteceği, evlenme dairelerinin törenlerine de izin verildiği ifade ediliyordu. Haberin altında "yasaklara riayet edilmezse Siklyönetim müsaadeleri kaldıracak" uyarısı da bulunmaktaydı (Hürriyet, 9 Mayıs 1960).

İstanbul ve Ankara'da bu yasaklar kapsamında tren, otobüs ve vapur seferlerine yeni düzenlemeler getirildi. Sokağa çıkma yasaklarına paralel olarak son seferlerin yapılacağı, yasağın başlamasıyla İstanbul ve Ankara'ya ulaşan trenlerdeki yolcuların sabaha kadar vagonlarında kalacakları açıklandı. Hürriyet gazetesi "vapurlar ve trafik kisaltılan gece yasağına ayarlandl" başlı̆̆ıyla verdiği haberde ayrıca Kızılay ve Sıhhiye arasındaki durakların değiştiğini, Taksim'deki durakların da kaldırıldığını yazıyordu (Hürriyet, 7 Mayıs 1960).

19 Mayıs'ta İstanbul ve Ankara'da 19 Mayıs törenlerinin yapılmayacağı tebliği üzerine, Cumhuriyet gazetesi 20 Mayıs tarihli sayısında "Yurtta 19 Mayıs kutlanışı" başlığı altında Sıkıyönetim olmayan şehirlerde törenler yapıldığını, gençlerin Atatürk anıtlarına merasimle çelenk koyduklarını yazıyordu (Cumhuriyet, 20 Mayıs 1960).

22 Mayıs 1960 tarihinde bir gün öncesinde meydana gelen olaylar sebebiyle tedbirlerin artırıldığı görülmektedir. Bu kapsamda sokağa çıkma yasağı yeniden genişletildi ve 22:00'den 05:00'e kadar uzatıldı. Ankara'ya ülke içinden veya ülke dışından gönderilen telgraf ve mektuplara sansür konuldu. Ayrıca, radyo, telefon ve telsizlere de el konuldu. Milliyet gazetesi bu haberi "Ankara'da yeni yasaklar konuldu, telgraf, mektup sansüre tabi; bütün diğer muhabere vasitaları da kontrol edilecek" manșetiyle duyurdu (Milliyet, 23 Mayıs 1960). Cumhuriyet gazetesi de "Ankara'da

929 Nisan'da İzmir'de İstanbul ve Ankara'da yaşanan hadiselerle ilgili olarak öğrenciler tarafından sessiz yürüyüş yapıldı ve herhangi bir taşkınlık yaşanmadan öğrenciler dağıldılar (Milliyet, 30 Nisan 1960). 
mektup ve telgrafa sansür konuldu" başlığıyla verdiği haberde, şehirde gezinti maksadıyla beş kişinin dahi bir araya gelerek dolaşmalarının yasaklandığ 1 aktarılıyordu (Cumhuriyet, 23 Mayıs 1960).

Yukarıda da belirtildiği üzere, Tahkikat Komisyonu'nun ve Sıkıyönetim Komutanlığı'nın yasaklarına rağmen olaylarla ilgili resim, karikatür ya da farklı türlerde haberler yayınlayan gazetelerin anında kapatılacağı yönünde karar alınmıştı. Bu şekilde yayın yaptığ 1 tespit edilen gazeteler anında kapatılarak ilgili yayınları toplatılıyordu. Bu nedenle gazetelerin kapatılmasına sebep olan haberlerin içeriği hakkında ne yazık ki herhangi bir bilgi mevcut değildir. Bir gazetenin kapatılması kararı diğer gazeteler de çok kısa bir şekilde veriliyordu. Ayrıca, kapatılan gazeteler tekrar yayınlanmaya başladıklarında dahi kapatılmalarıyla ilgili herhangi bir değerlendirme yapamıyorlardı.

Öğrenci olayları çerçevesinde ilk kapatılan gazete Cumhuriyet oldu. 30 Nisan'da İstanbul Sıkıyönetim Komutanlığı tarafından yayınlanan 11 numaralı tebliğle gazetenin ilk sayfasında neşredilen karikatürlerin halkı teşvik ve tahrik edici mahiyette olduğu gerekçesiyle gazete on gün süreyle kapatıldı ve 30 Nisan tarihli nüshaları toplatıldı (BCA. 010.09.7.23.7.3.16). 4 Mayısta da İstanbul'da yayınlanan Yeni Sabah gazetesi, Güney Kore'de yaşanan protesto fotoğraflarını yayınlayarak halkı teşvik ve tahrik ettiği gerekçesiyle 10 gün süreyle kapatıldı ve 4 Mayıs'ta basılan nüshaları toplatıldı (BCA. 010.09.7.23.7.3.18).

5 Mayıs'ta Milliyet gazetesi "Yeni Sabah da kapatıldı" başlığıyla birinci sayfadan verdiği haberde, Güney Kore'de profesörlerin gösterilerine ait bir fotoğraf yayınlayan gazetenin 10 gün süreyle kapatıldığını aktarmaktadır. Haberde gazetenin kapatılmasıyla ilgili olarak İstanbul Sıkıyönetim Komutanlığı'nın yayınladığı 22 numaralı tebliğ yer almaktadır. Tebliğde Güney Kore'de yaşanan olayları gösteren fotoğraf yayınlayarak halkı tahrik etmek gayesi güdüldüğü iddia ediliyordu. ${ }^{1}$

7 Mayıs'ta Kızılay'da meydana gelen hadiselerin fotoğraflarının basılmasının yasaklanmasına rağmen, Zafer gazetesinin resimleri basmış olmasından dolayı bir hafta süreyle kapatıldığı açıklandı (BCA. 010.09.7.23.7.3.8). Milliyet gazetesi, Kızılay’daki hadiselerin resminin tezahürat olarak basılmasının neşir yasaklarına aykırı görüldüğünden, DP'nin resmi yayın organı olan Zafer gazetesinin bir hafta süreyle kapatıldığını yazıyordu. Ankara Sıkıyönetim Komutanlığı; Kızılay Meydanı'nda yaşanan hadiseleri protesto olarak kabul ve izah ettiğinden, bu hadiselerin yazı ve

\footnotetext{
1 “4 Mayls 1960 tarihli İstanbul'da intişar eden 7205 sayll Yeni Sabah gazetesinin ilk sayfasinın birinci ve ikinci sütunlarını bir punto halinde işgal ederek basılan ve profesörlerin gösterisi başlı̆̆ını taşıyıp, Güney Kore'de cereyan eden bir protestoyu gösteren fotoğraf, mahiyet itibariyle efkarı umumiyeyi teşvik ve tahrik edici mahiyette görüldü̆̈̈̈ gibi aynı zamanda Sikıyönetim emirlerine aykırı bulunduğundan 3822 sayıl Sikıyönetim Kanunu'nun 3. maddesinin 4. Fikrası mucibince mezkur gazetenin neşrinin 10 gün müddetle menine ve neşredilmiş olan aynı nüshaların toplattırılmasına karar verilmiştir" (Milliyet, 5 Mayıs 1960).
} 
fotoğraflarla neşrinin yasak kapsamına alındığından, Zafer gazetesine kapatma cezası verilmişti ${ }^{1}$

8 Mayıs'ta Milliyet gazetesi Sıkıyönetim Komutanlığı'nın yasaklarına riayet etmediği gerekçesiyle 15 gün süreyle kapatılarak nüshaları toplatıldı. Haftada iki kez yayınlanan Hür Adam gazetesi ise 10 Mayıs tarihli yayınından dolayı, aynı gerekçelerle 10 hafta (BCA. 010.09.7.23.7.3.19), 18 Mayıs'ta Akşam gazetesi 20 gün müddetle (BCA. 010.09.7.23.7.3.21), 23 Mayıs'ta ise Haber Gazetesi 10 gün süreyle kapatıldı (BCA. 010.09.7.23.7.3.12).

Gazetelere ortalama 10 günlük kapatma cezaları verilirken, 8 Mayıs'tan itibaren Milliyet gazetesi 15 gün, Akşam gazetesi 20 günlük bir ceza aldığı görülmektedir. Hür Adam gazetesi ise 10 haftalık ceza alarak bu noktada en ağır muameleye maruz kalmıştır.

\section{Basında 27 Mayıs Darbesi}

27 Mayıs darbesi, en üst rütbesi albay olmak üzere bir grup subay tarafindan planlandı. Demokrat Parti'nin on yıllık iktidarı bu müdahale ile sona ererken Türkiye kamuoyu darbe ile tanışıyordu (Topçu-Akılmak Topçu, 2017: 64). 27 Mayıs sabahı Cumhurbaşkanı Celal Bayar, TBMM Başkanı Refik Koraltan ve İçişleri Bakanı Namık Gedik başta olmak üzere DP milletvekilinin tamamı gözaltına alındı ve Harp Okulu binasına götürüldü. Adnan Menderes ise Kütahya yolunda tutuklanarak Eskişehir'e, oradan da Ankara Harp Okulu'na götürüldü. Böylece darbenin ilk aşaması tamamlandı (Burçak, 1998: 757-758). ${ }^{1}$

27 Mayıs darbesi sonrası basında orduya ve darbecilere methiyeler dizen haberler yapıldığı görülmektedir. Cumhuriyet gazetesi, "memleketin bu günkü buhranina ve kardeş kavgasina mani olmak üzere kahraman Türk ordusu bütün memlekette dün gece sabaha karşı idareyi ele aldı. Maksat tarafsı bir idarenin nezaret ve murakabesi altında süratle yeni seçimlere gitmek ve bu adil seçimler neticesinde hangi taraf kazanırsa idareyi onun ellerine devretmektir" manşetiyle darbeyi ve izlenecek yolu duyuruyordu (Cumhuriyet, 27 Mayis 1960).

Akşam gazetesi ise "İkinci Cumhuriyet Kuruluyor" tarzında iddialı bir manşetle darbenin yanında olduğunu ilan ediyordu (Akşam, 27 Mayıs 1960). Vatan gazetesi “ordu idareyi ele aldl" manşetini atarken, Silahlı Kuvvetlerin 27 Mayıs günü saat 03:00'dan itibaren bütün yurtta duruma hakim olduğunu, darbenin radyolarla yurda ve bütün

1 “60 Mayıs 1960 Cuma günü Ankara'da intişar eden 3619 sayılı Zafer gazetesinin ilk sayfasının sağ yukarısında İçişleri Bakanlı̆̆ı'ndan tebliğ olunan yazıda 5 Mayıs 1960 günü saat 17:00'da Kızılay Meydanı'nda vuku bulan hadiseler protesto olarak kabul ve izahı yapılmış ve Kumandanlı̆̆ımızın 14 numaralı tebliği ile de bu hadiselerin yazı ve fotoğraflarla neşri yasak edilmişken, aynı yazının hemen sol kısmında bu olaylar esnasında çekilen fotoğrafların tezahürat olarak basılması mevcut neşir yasağına aykırı görüldügünden 3822 sayll kanunun 3. maddesinin 4. Fikrası gereğince mezkur gazetenin tab ve neşrinin bir hafta süreyle men edilmesine ve bu tarihli tab ve neşredilmiş nüshalarının toplattırılmasına karar verilmiştir” (Milliyet, 8 Mayıs 1960).

130 Nisan 1959'da Uşak ziyaret̊ esnasında İsmet İnönü'nün vurulması için emir verdiği iddia edilen Uşak Valisi İlhan Ergün 1 Haziran'da tutuklanarak Ankara'ya getirildi. Elleri kelepçelenen valinin bileklerine İnönü'ye atılan taşa mukabil bir taş bağlanmıştı (Milliyet, 2 Haziran 1960). 
dünyaya duyurulduğunu aktarıyordu (Vatan, 27 Mayıs 1960). Hürriyet gazetesi de darbeyi "Türk ordusu vazife başında, silahlı kuvvetlerimiz bütün yurtta idareyi fillen ele aldl" manşetiyle duyurdu (Hürriyet, 27 Mayıs 1960).

Tercüman gazetesi darbeyi Türk Silahlı Kuvvetleri'nin milli inkılap hareketi şeklinde göstererek "milletçe bayram sevinci içerisindeyiz" diyordu. Gazete, Bayar, Menderes ve DP'li vekiller ile Tahkikat Komisyonu üyelerinin nezaret altına alındığını, meclisin feshedildiğini, üniversitelerin açılacağını ve kısa zamanda seçimlere gidileceğini aktarmaktaydı. Ayrıca gazete başka bir haberde darbenin bütün dünyada olumlu karşılandığı, yabancı radyoların Türkiye'de ordunun başardığı bu hareketi takdirle andıklarını ileri sürüyordu (Tercüman, 28 Mayıs 1960).

Milliyet gazetesi ise 28 Mayıs'ta darbeyi duyururken, meclisin feshedildiğini, yeni anayasa hazırlanana kadar siyasi faaliyetlerin durdurulduğunu, hapisteki gazeteci, subay ve öğrencilerin tahliye edildiğini ve de kapatılan gazetelerin açıldığını duyuruyordu (Milliyet, 28 Mayıs 1960).

30 Mayıs'ta gazeteler DP hükümetinin İçişleri Bakanı Namık Gedik'in intihar ettiğini yazıyordu. Gedik'in darbeciler tarafından öldürüldüğü iddiaları da olmakla beraber sinir krizi sonrasında, gözaltına alındığı Harp Okulunun üçüncü katından atlayarak intihar ettiği duyuruldu (Vatan, 31 Mayıs 1960). Gedik'in ölümü, darbe sonrası yaşanan ilk trajik ve nasıl olduğu açıklı̆ga kavuşmamış bir olay olarak kayıtlara geçti (Dikici, 2014: 28).

\section{27 Mayıs Darbesi Sonrası Basında İstanbul-Ankara Öğrenci Olayları}

27 Mayıs darbesi yapıldıktan sonra Askeri Cunta tarafından "ülkenin çok tehlikeli bir uçurumdan son dakikada kurtarıldı̆̆ " şeklinde yoğun bir propaganda yapılmaya başlandı. Bununla da yetinilmeyerek DP iktidarı akıllara durgunluk veren suçlamalarla itham edildi. Bir taraftan İstanbul Bayezid Meydanında hükümet aleyhine gösterilerde bulunan öğrencilerin yüzlercesinin gizlice öldürülerek cesetlerinin bilinmeyen yerlere gömüldüğü, bir kısmının da Et-Balık Kurumu'nun kombinalarında kıyma şekline dönüştürerek hayvan yemi haline getirildiği iddia edilirken, diğer taraftan Harp Okulunun 1.500 öğrencisinin toptan imha edilmesi için hazırlıklar yapıldığı öne sürülüyordu (Burçak, 1998: 783-784). Cinayetlere ilişkin iddiaları dile getirenlerin başında İstanbul Üniversitesi Rektörü Sıddık Sami Onar geliyordu. Onar, yüzlerce gencin öldürülerek muhtelif mezarlara gömüldüğü yönünde basına demeçler verdi. Bazı Milli Birlik Komitesi yetkililerinin de dile getirdiği bu asılsız iddialar 27 Mayıs darbesinden sonra uzun süre basında yer aldı ve teksir makinelerinde basılıp dağıtıldı. Hatta darbeden sonra Et-Balık Kurumu kuşatılarak öğrenci cesetleri arandı.

29 Mayıs’ta Tercüman gazetesi üniversite olaylarında 90 öğrencinin kayıp olduğunu ve bunların nereye gömüldüklerinin araştıııldı̆̆ını yazıyordu (Tercüman, 29 Mayıs 1960). Aynı tarihte Milliyet gazetesi, İstanbul Üniversitesi'nden bir grup öğretim üyesi ve öğrencinin Askeri İdare Emniyet Müdürü Yarbay Vahit Erdoğan'ı ziyaret ederek olaylarda öldürülen arkadaşlarının yerlerini öğrenmek istediklerini, buna mukabil Emniyet Müdürünün de yakın bir zamanda bu konuda açıklama yapacağı karşılığını verdiğini yazıyordu (Milliyet, 29 Mayıs 1960). 
2 Haziranda Vatan gazetesi İstanbul-Ankara'daki öğrenci olayları ile alakalı olarak "Ankara'da binlerce üniversitelinin kanlarıyla süslenmiş bir bayrağı teslim alan Cemal Gürsel gençlere hitap etti" manșetini atıyordu. Haberde Gürsel'in gençlere "sizler asil hareketinizle yalnı zalimleri korkutmadını, ayn zamanda milletin ve hepimizin ümitlerine de ışık tuttunuz" dediğini aktarıyordu (Vatan, 2 Haziran 1960).

Milliyet gazetesi BBC radyosuna dayanarak; "buzhanelerden toplu halde cesetler çıktl, cesetlerin ekserisinin protestolarda öldürülen öğrenciler olduğu açıklandı" diyerek verdiği haberde, Milli Birlik Komitesi adına konuşan ve ismi belirtilmeyen bir albayın bu açıklamayı yaptığı ve tahkikatın devam ettiği belirtiliyordu (Milliyet, 2 Haziran 1960).

Akşam gazetesi 4 Haziran'da “cesetler yem makinalarında kiyllip toz haline getirilmiş" manşetiyle gösterilere karışan öğrencilerin vahşice katledildiğini iddia ediyordu. Haberde Milli Birlik Komitesi'nin birçok ipucu ele geçirdiği ve kayıp öğrenci velilerinin resmi makamlara başvurmasının istendiği belirtiliyordu (Akşam, 4 Haziran 1960). Hürriyet gazetesi ise cesetlerin toz haline getirildiğine ilişkin ihbardan söz ederek, halktan aramalar için yardım talep ediyordu (Hürriyet, 4 Haziran 1960). Milliyet gazetesi "korkunç ihbarlar" başlığıyla verdiği haberde, Milli Birlik Komitesi tarafından hayatını kaybedenlerle ilgili bir tebliğ yayınlandığını, tebliğde bir kısım gençlerin öldürüldüğüne dair haberler alındığı ifade edilmekteydi. MBK, cinayetlerin ortaya çıkartılması için evlatlarını kaybeden ailelerin ilgili birimlere başvurmalarını istiyordu. Milli Birlik Komitesi tarafindan 4 Haziran'da yayınlanan ve basında da geniş yer bulan tebliğ şu şekildeydi:

"1- Kahraman ve fedakâr üniversiteli gençlerimizin 28 Nisan 1960 'tan 27 Mayls 1960 tarihine kadar hürriyet uğrunda yapttklart masum ve imanl gösteriler sırasında bu asil gençliğimize eski hükümetçe coplarla, kılıçlarla hücum ettirildiği, hiç müdafaa vasıtası olmayan gençlerin teşkil ettiği kitleler üzerine insafslzca ateş açıldığg, kendilerinin ă̆ır şekilde dövülüp yaralandiğı ve birçok gencin öldürüldüğ̈̈ artık muhterem halkımızın malumu olmuştur.

Hürriyet şehitlerimizin tespiti işine silahl kuvvetlerimizin idareyi ele aldiğg andan itibaren ehemmiyetle devam edilmektedir. Bu güne kadar yapılan inceleme ve araştırmalarda birçok ipuçları ele geçirilmiştir. Cinayetleri yapanların kendi suçlarını örtmek ve cesetleri yok etmek için akla hayale gelmeyecek canavarca tedbirlere başvurduklart anlaşllmaktadır. Şehitlerin gizli yerlere gömüldükleri, ıssız yerlerdeki kayalıklara atıldikları, bir kısmının buzdolaplarına konulduğu ve bir kisminin da hayvan yemi yaplan makinelerde klyılarak toz haline getirildiği hakkinda korkunç haberler alınmaktadir. Aramalara dikkat hassasiyetle devam edilmektedir. Korkunç bir vahşetle işlenen bu cinayetler er veya geç mutlaka meydana çıkartılacak ve sayın umumi efkara arz edilecektir. 
2- Tespit edilen hürriyet şehitlerimizin ebedi istirahatgahlarına bir an evvel tevdi edilmeleri için Milli Birlik Komitesince bu hususlar kararlaştırılmıştır.

a) Son hadiseler sırasında hürriyet ŭgruna şehit düşen gençlerimizle 27 Mayıs'ta silahlı kuvvetlerimizin yaptığ inklap hareketinde şehit olan Kara Harp Okulu ögrencisi Teğmen Ali İhsan Kalmaz 10 Haziran 1960 günü Ankara'da yaplacak büyük bir merasimle Anıtkabir'in yanında tesis edilecek hürriyet şehitliğine gömüleceklerdir. Askeri ve mülki erkan ile üniversitelilerin, askeri okulların, vilayet temsilcilerinin ve barolartn ve diğer daire ve müessese temsilcilerinin katılacaklart bu merasime ait program ayrica ilan edilecektir. "(Milliyet, 4 Haziran 1960: $5)$.

Öldürülen öğrenciler konusunda İstanbul Üniversitesi Rektörlüğü de harekete geçti. 3 Haziran 1960'ta İstanbul Üniversitesi Rektörlüğü İstanbul ve Ankara olaylarında hayatını kaybeden gençlerin sayısını tespit etmek amacıyla anket açıldığını duyurdu. Anket çalışmasına göre, radyo ve gazete vasıtasıyla ilanlar yapılacak, çocuklarından haber alamayan aileler üniversiteye müracaat etmek suretiyle ölenlerin sayısının tespiti sağlanacaktı. İstanbul Üniversitesi Rektörü konuyla ilgili yapmış olduğu basın toplantısında ölenlerin sayısını tespit etmek üzere ayrıca bir komisyon kurulduğunu ifade ettikten sonra: "o günlerde gece kamyonlarla mezarlıklara ölüler götürüldüğü görülmüştür” diyordu. Konuşmasının devamında ölen öğrenciler için üniversite bahçesine abide dikmek gayesiyle Beyazıt Emniyet Sandığı'nda 2104 numaralı bir hesap açıldığını, yardım yapmak isteyen herkesin bu hesaba para yatırabileceğini duyurdu. Ayrıca, Güzel Sanatlar Akademisindeki mimarlar tarafindan kendilerine bir abide maketi sunulduğunu, istişarelerden sonra karar verileceğini sözlerine ekledi (Milliyet, 3 Haziran 1960: 5).

Gazeteler, öldüğü iddia edilen öğrenciler için hürriyet anıtı dikilmesi amacıyla kampanya başlattı. Akşam gazetesi bu konuda çalışmalara öncülük ederek anıt yapılması için bağış yapanların listesini ve bağış miktarını "ilk bağışçıların listesi" başlığıyla okuyucularına duyurdu (Akşam, 28 Mayıs 1960). ${ }^{1}$ 'Sonrasında “hürriyet anıtı Aķşam'ın değil milletin gençliğe armăganıdır" sloganıla İstanbul, Ankara ve İzmir'de toplanan bağış miktarı 75.000 lirayı, (Akşam, 30 Mayıs 1960) ertesi gün 100.000 lirayı aştı (Akşam, 31 Mayıs 1960). Gazete takip eden günlerde listeyi yayınlamaya devam etti.

Milliyet gazetesi de öğretim üyeleri ve gençlerin talebi üzerine üniversite bahçesinde anıt dikilmesi için bir kampanya başlattı. Kampanya o kadar başarılıydı ki, ilk gün 48.000 lira toplandı (Milliyet, 29 Mayıs 1960). İkinci gün yardım miktarı 70.430 liraya ulaştı. Milliyet gazetesi, hayatını kaybeden öğrencilerin üniversite bahçesine gömülmesi

\footnotetext{
${ }^{1}$ Aynı gazete 29 Mayıs’ta "abidẻye yardıma her Türk koşuyor" diyerek anıta bağış yapanların listesini yayınlamaya devam ediyordu (Akşam, 29 Mayıs 1960).
} 
yönünde Milli Birlik Komitesi nezdinde gençler tarafindan teşebbüslerde bulunulduğunu da aktarıyordu (Milliyet, 30 Mayıs 1960).

3 Haziran 1960 tarihli Akşam gazetesi öğrencilerin Anttkabir'e gömüleceğini duyurdu (Akşam, 3 Haziran 1960). Yayınlanan bu haberden bir hafta sonra, 10 Haziran'da, Anıtkabir'de yapılan törende cenazeler toprağa verildi. Defnedilenler Turan Emeksiz, Nedim Özpolat, Ersan Özey, Harp Okulu öğrencisi Gültekin Sökmen ve Teğmen Ali İhsan Kalmaz'dı. Cemal Gürsel ve İsmet İnönü törene katılmazken, törenden sonra mezarlara çelenk koymak için gelecekleri bilgisi veriliyordu (Milliyet, 11 Haziran 1960: 1-5). ${ }^{1}$

Gazeteler öğrenci olayları kapsamında hükümetin Harp Okulu öğrencilerini hedefe koyduğu ve canice planlar hazırladığını iddia etmeye başladılar. Yine Milli Birlik Komitesi yetkililerinin açıklamalarına dayandırılan haberler oldukça ilginçti. 9 Haziran 1960 tarihli Ulus gazetesinde: "sabık iktidarın Harp Okulu öğrencileri için tasarladığ suikast tasarısı dün açılklandı" manşetiyle Cemal Gürsel'in subaylarla yaptı̆ğ konuşmadan bahsediyordu. Haberde Harp Okulu'nun makinalı tüfekler ve bombayla imha edileceği, öğrencilerin yürüyüşe çıkartılıp yolda kurşunlanarak ya da evlerinden teker teker alınarak öldürülecekleri iddia ediliyordu (Ulus, 9 Haziran 1960).

30 Mayıs'ta yabancı basın mensuplarının sorularını yanıtlayan Milli Birlik Komitesi Başkanı Cemal Gürsel: "asil milletimiz yaşadığı karanlık günleri bütün çıplakllğı ile ögrrenecektir" diyerek yapılanlara destek verdi (Milliyet, 29 Mayıs 1960). 4 Haziran 1960 tarihinde Devlet ve Hükümet Başkanı Cemal Gürsel, Milli Savunma Bakanlığı'nda subay ve astsubaylara hitaben yaptığ 1 ve basında da yayınlanan konuşmasında, DP'lilerin Harp Okulu öğrencilerini ortadan kaldırmak için planlar yaptıklarını iddia ediyordu:

"Bizim yıktı̆̆ımız insanlar çok mücrimdir. Tarihte bunlar kadar mücrim insan tasavvur edilemez ve yoktur. Neronlar belki bunlar seviyesine ulaşabilirler. Bunların içine düştükleri badireden kurtulmak için en çıkar yolu ordu arasına fesat sokmakta arayacaklarından hiç şüpheniz olmasın. Bunlara alet olursak bu yaptığımız mukaddes mücadelenin bütün faziletleri elimizden gider. Memleket de gider. Yaptı̆̆ımız mücadele koltuk için değil hürriyet içindir. Mazlumların gasp edilen hakların zalimlerin elinden istirdat mücadelesidir. Düşünün ki bu adamlar, ordumuzun irfan kaynağı biricik harbiyemizi ve burada yurt aşkı ile yanan bin beş yüz kişilik masum çocuklarl, vatanperver evlatlarımızı kurşuna dizmeyi, toptan imha etmeyi tasavvur etmiş insanlardır. Bu bir rivayet değildir arkadaşlar, bunun delilleri vardır. Şöyle oluyor: Harbiyelilerin yürüyüşünden sonra ziyadesiyle telaşlanan sabık hükümet adamları Çankaya'da toplaniyorlar. Aralarında Ankara Valisi Dilaver Argun da var. Durum müzakere ediliyor. Celal Bayar 30 milyon insan arasindan 1500 kişinin yok edilmesinde hiçbir mahzur

123 Ağustos 1988 'de cenazeler ${ }^{4}$ Anıtkabir'den Cebeci Şehitliği’ne nakledildi. (Temizgüney, 2018: 191). 


$$
\begin{aligned}
& \text { olmadığını söylüyor. Bunlar ne pahasına olursa olsun imha } \\
& \text { edilmelidir. }{ }_{5}^{1}
\end{aligned}
$$

Nasıl imha edelim: Harbiye'de meydana toplayalım. Bombalarla makineli tüfeklerle kendi adamlarımı tarafindan imha edelim. Veya yürüyüşe çıkartalım, yolda tertibat alalım, adamlarımızla bunları kurşundan geçirelim. Veya bu da tehlikeli görülüyorsa izin verelim herkes evine gitsin, sonra tekrar evlerinden toplayıp imha edelim... Işste dikkatinizi bu noktalara çekmek için sizi buraya topladım." (Milliyet, 9 Haziran 1960: 1-5).

5 Haziran'da Akşam gazetesinde: “korkunç cinayetler aydınlanıyor, bir çukura gömülen 3 ceset bulundu” manşetinin altında Silivrikapı mezarlığında ikisi erkek biri kız olmak üzere üç gence ait cesedin bir çukurdan çıkartıldığı, erkeklerin atlet ve külotlarıyla, kızın ise gömleğiyle gömüldüğünün tespit edildiği iddia ediliyordu (Akşam, 5 Haziran 1960). Fakat olay hakkında daha fazla bilgi verilmiyordu.

Öğrenci olayları sırasında DP iktidarının karşı hamle olarak halkı silahlandırdığına dair iddialar da basında dillendirildi. Farklı yerlerde gömülü silah ve askeri elbiseler ele geçirildiği, bu silahlarla akla hayale gelmeyecek planlar yapıldığı iddia ediliyordu. Ulus gazetesi "sabık iktidarın yarıda kalan tertibi" başlığı altında İstanbul Taşlıtarla'da parayla tutulan adamlara dağıtılmış 7.000 silah ve asker elbisesi ele geçirildiği, depolar bulunduğu ve tahrip teşkilatının yakalandığını, yine aynı gazetede "memleketimiz ve halkımı büyük tehlike atlattı" manşetiyle bu silahlarla yüzlerce kişinin yok edileceği, sahte askerler tarafindan yapilacak bir terör hareketiyle halk ile ordu arasına nifak sokulacağı iddiasına yer veriliyordu (Ulus, 30 Mayıs 1960). Aynı konuyla alakalı olarak Tercüman gazetesinde ise "Menderes 'in korkunç tasavvurları meydan çıktı" manşetiyle uydurma bir halk hareketi hazırlanacağ 1 , birçok kişinin insafsızca öldürüleceği iddia ediliyordu. Gazetede Ziraat Bankası'nın ambarında 2.000 silah ve çok miktarda asker elbisesi ele geçirildiği aktarılıyordu (Tercüman, 31 Mayıs 1960). Başka bir sayıda ise depoda 5.700 mavzer ve binlerce tabancanın bulunduğu duyuruldu. ${ }^{1}$

Milli Birlik Komitesi Basın Bürosu Başkanı Kurmay Binbaşı Necati Aktaş 1 Haziran'da, DP hükümetinin zirai mücadele bahanesiyle 3.700 tüfeği dağıtmak istediğini, fakat ordunun son anda buna engel olduğunu açıkladı (Milliyet, 1 Haziran 1960: 5).

\section{Sonuc}

14 Mayıs 1950 seçimleriyle iktidara gelen DP, 27 Mayıs darbesine kadar geçen süreçte tek başına iktidarda kalmayı başarabilmişti. Özellikle 1957 seçimlerinden sonra

\footnotetext{
1 Söz konusu iddialar ve Bayar'ın' Yassıda mahkemelerindeki savunması için bkz: İlyas Topçu, İstanbul-Ankara Olayları Davası'nda Celal Bayar'ın Yargılanması, Sosyal Bilimlerde Güncel Araştırmalar, IKSAD Yayınevi, Ankara, 2020.

1 Haberin devamında, bu silahlárın asker elbisesi giydirilmiş kimselere dağıtılarak halka ateş açtırılacağı ve halkın orduya düşman edileceği iddia edilmekteydi (Tercüman, 1 Haziran 1960).
} 
iktidarla muhalefet arasında ilişkiler oldukça gergin bir hal almıştı. 27 Mayıs darbesinden bir ay önce kurulan Tahkikat Komisyonu ve ardından bu komisyona geniş yetkiler tanıyan Salahiyetler Kanunu'nun mecliste kabul edilmesinden sonra İstanbul ve Ankara'da üniversite öğrencilerinin başını çektiği protesto gösterileri başladı. Gösterilerin hedefinde hükümet bulunuyordu. Bu yüzden hükümetin tavrı sert oldu ve bu iki şehirde sıkıyönetim ilan edildi. İstanbul ve Ankara Sıkıönetim Komutanlıkları tarafından sürekli olarak tebliğler yayınlandı ve her gün yeni yasaklar konuldu. Söz konusu yasaklar basına yönelik sert hükümler de içeriyordu. Bu süreçte basına sansür uygulandığı için dönemin gazetelerinde İstanbul ve Ankara'da yaşanan protestolarla ilgili herhangi bir bilgi paylaşılamıyordu. Tahkikat Komisyonu ya da Sikıyönetim Komutanlığı protestolarla ilgili resim, karikatür ya da farklı türlerde haberlerin yayınlamasını yasakladı. Buna uymayan haber ya da görsellerin yer aldığı gazeteler anında kapatıldı ve ilgili sayıları da toplatıldı. Bu nedenle protestolarla ilgili basında Sıkıyönetim Komutanlıklarının ve Tahkikat Komisyonu'nun tebliğleri dışında çok fazla bilgi ve detay yer almamaktadır.

İstanbul ve Ankara'da başlayan ve Sıkıyönetim ilanına rağmen kontrol altına alınamayan olaylar 27 Mayıs darbesiyle neticelendi. Darbe ulusal basında sevinçle karşılandı. Darbecilere methiyeler dizen haberler yapıldı. Askeri cunta tarafından ülkenin çok tehlikeli bir uçurumdan son anda kurtarıldığı şeklinde yoğun propagandaya başland. Yönetime hakim olunmuştu fakat hakimiyetin sürdürülmesi gerekiyordu. Bu sebeple de propaganda yöntemleri kullanılmalıydı. Cunta, idareyi ele alır almaz DP iktidarını akıllara durgunluk veren suçlamalarla itham etmeye başladı. Müdahalenin sebepleriyle birlikte meşruiyetini de kamuoyuna anlatmak istiyordu. Suçlamalar arasında en fazla dikkat çekeni İstanbul-Ankara olaylarında çok sayıda öğrencinin hükümet tarafından canice öldürüldüğü iddiasıydı. Bunların çoğu Milli Birlik Komitesi yetkililerinin yaptığı açıklamalara dayandırıldı. Bu iddiaların tamamı basında en geniş şekilde yer aldı. İddialar o kadar etkiliydi ki, öldürüldüğü iddia edilen öğrencilere bir anıt yapılması için gazeteler kampanyalar başlattı.

Yukarıda da ifade edildiği gibi askeri müdahalenin halkta bir karşılık bulabilmesi ve meşruiyeti için İstanbul-Ankara olayları özellikle kullanıldı. Çünkü üç genel seçim kazanmış ve on yıl iktidarda kalmış bir partinin siyaset sahnesinden el çektirilmesi halk nezdinde ters tepkilere sebep olabilirdi. İşte bu nedenle darbeden sonraki günler çok önemliydi. Cuntacılar tarafindan ortaya atılan akıl almaz iddialar askeri yönetimin gölgesindeki basında etraflıca yer aldı. Halkta çok ciddi bir karșılığı olan DP'nin iktidardan el çektirilmesinden sonra askeri müdahale karșıtı herhangi bir olayın yaşanmamış olmasında bu propagandanın çok önemli yerinin olduğunu vurgulamak gerekir. Nitekim ülke genelinde kontrolün tam olarak sağlanmasından sonra İstanbulAnkara olaylarıyla ilgili akıl almaz iddiaların bir anda cuntacıların ve basının gündeminden düşmüş olmasının bununla alakalı olduğu söylenebilir. 


\section{Kaynaklar}

Arşiv Belgeleri

BCA. 010.09.7.23.7.3.12.

BCA. 010.09.7.23.7.3.14

BCA. 010.09.7.23.7.3.15.

BCA. 010.09.7.23.7.3.18

BCA. 010.09.7.23.7.3.19.

BCA. 010.09.7.23.7.3.21

BCA. 010.09.7.23.7.3.8

BCA. 010.09.7.23.7.40

BCA. 010.09.7.23.7.41.

BCA.010.09.7.23.7.3.16.

\section{Gazeteler}

Nadir Nadi, “Nasıl bir rejime gidiyoruz?” Cumhuriyet, 27 Nisan 1960.

Yakup Kadri Karaosmanloğu, “Niçin?niçin?” Ulus, 28 Nisan 1960.

Akşam.

Cumhuriyet.

Hürriyet.

Milliyet.

Tercüman.

Ulus.

Vatan.

\section{Meclis Tutanakları}

TBMM Zabit Ceridesi, 18 Nisan 1960, Cilt 13, Devre 11.

TBMM Zabut Ceridesi, 27 Nisan 1960, Cilt 13, Devre 11. 


\section{Kitap ve Makaleler}

Akça B. ve Kıyanç S. (2018). "CIA ve 27 Mayıs 1960 darbesi," Tarih Okulu Dergisi, 11(36), 528-564.

Başgil, A. F. (2007). Yakın maziden hatıra kalıntıları, (Müş̧rref Özdemir-Nazif Güner), Yağmur Yayınevi.

Bozdağ, İ. (2010). Celal Bayar Başvekilim Adnan Menderes, Truva Yayınları.

Bulut, S. (2009). "Üçüncü dönem Demokrat Parti iktidarı (1957-1960): siyasi baskılar ve Tahkikat Komisyonu," Akademik Bakış, 4(2), 125-145.

Dikici, A. (2014). "27 Mayıs 1960 askerî darbesi ve Türk polisi," Atatürk Araşstırma Merkezi Dergisi, 30(89): 11-59.

Emin-Yalman, A. (1970). Yakın tarihte gördüklerim ve geçirdiklerim (1945-1970), Rey Yayınları, Cilt 4.

Emre-Kaya, A.E. (2010). "Demokrat Parti döneminde basın-iktidar ilişkileri, İstanbul Üniversitesi Illetişim Fakültesi Dergisi," 1(39), 93-118.

Salim-Burçak, R. (1998) On yllın anıları (1950-1960), Nurol Matbaacılık.

Serhan-Yücel, M. (2001). Demokrat Parti, Ülke Kitapları.

Süreyya-Aydemir, Ş. (1998). İkinci adam, Remzi Kitapevi.

Taşyürek, M. (2009) Adnan Menderes, Anonim Yayıncılık.

Temizgüney, F. (2018). "1960 darbesine giden sürçte önemli bir kesit: İstanbul öğrenci olayları," Cumhuriyet Tarihi Araştırmaları Dergisi, 14(27), 181-211.

Topçu, İ. ve Akılmak-Topçu, S. (2017). "Adnan Menderes'in yargılanması ve idamı," Akademik Baklş Dergisi, 61. 59-80.

Topçu, İ. (2018). "İstanbul-Ankara olayları ve Demokrat Parti Hükümeti'nin uygulamaları," Kafkas Üniversitesi, Sosyal Bilimler Enstitüsü Dergisi, 22, 715-732.

Topçu, İ. (2019). "Adnan Menderes'in gözünden İstanbul ve Ankara olayları," Uluslararası Sosyal ve Beşeri Bilimler Araştırmaları Dergisi, 6(42), 2458-2469.

Topçu, İ. (2020). İstanbul-Ankara Olayları Davası'nda Celal Bayar'ın yargılanmast, Sosyal Bilimlerde Güncel Araştırmalar, IKSAD Yayınevi. 